\title{
WHEN ART IS RELIGION AND VICE VERSA. SIX PERSPECTIVES ON THE RELATIONSHIP BETWEEN ART AND RELIGION
}

\author{
FRANK G. BOSMAN* \\ Tilburg University
}

\begin{abstract}
In the discussion of religion and art, it is quite difficult to exactly define what makes art 'religious'. In this article, the author suggest six different perspectives in which a work of art—any work of art—could be interpreted as 'religious', as an embodiment of the complex relationship between art and religion. These perspectives are not mutually exclusive: one and the same art work could be approached on multiple levels at once. Nor do they disqualify other methodologies of studying art and religion. These perspectives provide conceptual windows to understand what people (could) mean when they discuss religious art. The six perspectives are: (1) material, (2) contextual, (3) referential, (4) reflexive, (5) ritual, and (6) existential. They vary from the more or less objective to the more subjective, and as such from artist-intended to viewer/listener-perceived (with or without help of clues provided by the artist and/or the object itself). The author illustrates who these different perspectives can vary in defining certain pieces of art as religious by using three very different case studies: the Isenheimer Altarpiece, one of Hugo Ball's famous sound poems, and the digital game Child of Light.
\end{abstract}

KEY WORDS: Art, religion, isenheimer altar, hugo ball, child of light

Religion and art are, and have always been, intimately intertwined with one another. Those who study religion, in all its vast and illusive iterations, appearances, and singularities, are bound to discover art both as an expression of religion and as a critique of religion. Similarly, those who study art, in all its similarities and differences, its tendencies and expressive forms, will sooner or later find the explicit and/or implicit inspirational dependencies of art and artists on the religious domain, and especially on what Rudolf Otto (1917) calls the mysterium fascinans et tremendum, the 'mystery that [simultaneously] fascinates and inflicts fear'. Institutionalized religion, espe-

* FRANK G. BOSMAN (PhD 2014, Tilburg University) is a senior researcher at the Tilburg Cobbenhagen Center (the Netherlands). Website: www.frankgbosman.nl. Email: f.g.bosman@tilburguniversity.edu. 
cially Christianity in the Western world, has been a major patron of the arts, but it has always struggled with art's potentially disruptive, heretical, and blasphemous nature, giving rise among other things to regular and fierce theological debates about the religious acceptability of depicting the divine at all. Mutatis mutandis, artists embraced their religious benefactors and their pious inclinations, although this entanglement has decreased as the 'secular experiment' began in the Western world, already started with Nietzsche's death of God, but popularized and effectualised in the revolution of the 1960s (I will return to this later), but they also maintained an aura of implicit and explicit criticism of religion, especially of religion in its institutionalized forms (Koestlé-Cate 2016; Sidell 2015).

In addition to the already illusive character of the two constitutive parts of this discussion-both defy all attempts to construct a concise, universally adapted and adopted definition (Davies 1991; Molendijk 1999)—scholars of the relationship between religion and art can engage with the subject from a multitude of theoretical and practical points of view: religion and art (Brown 2014), religion as art (Artland 1981), art as religion (Adams and Apostolos-Cappadona 1987), religious art (Howes 2007), artistic religion, art from religion, religion from art, and so forth. And it is not difficult to choose a particular time frame-Renaissance art, Gothic art, modern art-or a specific artist-Michelangelo (Prodan 2014), Rubens (Sauerländer 2011), Warhol (Dillenberger 1998)—all embedded with endless connections to the religious domain.

Apart from these considerations and complications, religion and art have both been reported to be in some sort of existential or identity crisis. Institutionalised religion is not in its best shape, to put it mildly, at least in Western Europe, a situation that has been alternatively described as 'secularization' (Casanova 2009; Joas 2009), 'de-institutionalization' (Streib 2007) or religious 'liquidation' (Groot 2018), and/or ascribed to broader sociological phenomena like the rise of individualism (Flanagan 2001) or the dominance of the model of multiculturalism (Morris 2014). As I have argued before (Bosman 2019:16), while institutionalised religion is decreasing rapidly throughout the Western world, the classic secularisation thesis as such is problematic on at least two levels: in the first place, secularisation is primarily a phenomenon of the Western, post-Christian world, and second, even in the secularised Western world religion is far from a relic from a long gone past (Nicholis 1979; Cobb 2005; Usselmann 2018).

Similarly, modern art has its own crisis to deal with (Sedlmayr 2006; Stakemeier and Vishmidt 2016). De Kesel addresses this issue in his article later in this volume. Commercialism that is making art into a mere economic commodity (Sassower and Cicotello 2000); mannerism that is turning artists into the embodiment of their own conceptual ideas (Hauser 1965); the 
decline of private, public and/or government sponsorship (Bennett, Kerrigan and O'Reilly 2012); the privileging of the banal over the enigmatic, and the scatological over the sacred (Kuspit 2005); the loss of value attributed to craftsmanship and metier (Frayling 2011); these all form the constitutive elements of a potentially endless discussion among artists, art critics, and art scholars about the very nature and condition of modern-day art.

The relationship between institutionalised religion-the Christian faith more specifically in the case of the Western world-and artistic communities has been deteriorating since the beginning of the $20^{\text {th }}$ century. New forms of art-Dadaism, cubism, futurism, conceptual art, and so forth-were being born in a frequently violent European history, marked by numerous conflicts, of which the First and the Second World War are most important, and were more often than not either (highly) critical of (institutionalised) religion or completely neglected it. Blasphemous art has always had its place within art itself, but it has now been elevated to a generally accepted phenomenon in the public domain (Pinkerton 2017; Korte 2014). Positive examples aside, the majority of churches have turned themselves away from these 'new' artists, out of dislike or incomprehension, to focus on the reproduction of more traditional and figurative pieces of art, resulting in a process of uncreative copying of the masters of the past and/or the creation of what can only be qualified as 'religious kitsch' (Brown 2000:128-159).

All these sociological tendencies and developments have created a rather strange diversion between church and museum, also as a collective of buildings or-better-specifically dedicated spaces. At the turn of the $20^{\text {th }}$ century, the churches lost their primary and obvious position as the funders, collectors, and exhibiters of art to the rising collective of galleries, travelling expositions, and exhibitions and museums with their fixed and temporary collections and presentations (Alexander and Alexander 2008; Simmons 2016). And although individual clergymen and women, individual congregations and artists have tried to bridge the gap, modern art is-typicallyno longer displayed in churches and cathedrals as extrapolations of religious messages and virtues, but instead it is collected in a dedicated place outside the religious realm. The obvious connection between the artistic and the religious world was never completely broken, but has become severely strained.

Intriguingly enough, museum and church seem to have assumed each other's role in modern society. Church building are increasingly transforming into museums that engage massive amounts of spiritual pilgrims and commercial tourists alike replacing the traditional church-goer, who is now presented with the ecclesiastical building as an appropriate 'space' to exhibit pieces of art from different ages within a particular and obvious context in which they can naturally exist. Church officials, both low and high, are usu- 
ally very keen to support this development since it generates the funds necessary to maintain the building and what is left of the church community itself, but also because this new function of the church building justifies its continuing existence and that of the religious traditions it represents in a modern world that is increasingly sceptical about institutionalised religion itself.

Conversely, museums have become the new sanctuaries of our world, and either shape our collective identity (Dalgleish 2000), form our sense of citizenship (Duncan 1994), conserve religious objects and practices of our precursors (Paine 2013) or even evoke a spiritual experience (Buggeln 2015). An impenetrable caste of artists, conservators, art connoisseurs, and art scholars guard the quality and 'purity' of our newest 'holy of holiest'.

Thus every discussion of religion and art is a perilous endeavour, full of clichés, one-sided debates, technical discussions, and conceptual faintness. And yet, this is exactly what this special issue of Perichoresis is trying to do, to reflect on the difficult and ever-changing relationship between the religious and the artistic. Six authors, all from Dutch academic institutes and experts in the fields of religion and art, will give their views and opinions on this relationship. In this introductory article, I will present and discuss six nonmutually exclusive perspectives on the relationship between religion and art, or more precisely, on how and when we can speak of 'religious art'. I will do this by analysing three dedicated case studies: an altarpiece, a sound poem, and a video game. I will argue that these three examples of art, in all its broadness, simultaneously can and cannot be identified as 'religious', depending on the perspective(s) that is taken.

\section{Religious Art: Six Perspectives, Three Case Studies}

To create some preliminary order in this conceptual chaos-how to speak about religion and art at the beginning of the $21^{\text {st }}$ century-I want to distinguish six perspectives in which a work of art-any work of art—could be interpreted as 'religious', as an embodiment of the complex relationship between art and religion. These perspectives are not mutually exclusive: one and the same art work could be approached on multiple levels at once. Nor do they disqualify other methodologies of studying art and religion. These perspectives provide conceptual windows to understand what people (could) mean when they discuss religious art.

The six perspectives are: (1) material, (2) contextual, (3) referential, (4) reflexive, (5) ritual, and (6) existential. They vary from the more or less objective to the more subjective, and as such from artist-intended to viewer/listener-perceived (with or without help of clues provided by the artist and/or the object itself). 
I will illustrate these six perspectives by means of three very different artistic 'objects': (a) the Isenheimer Altarpiece from 1516, (b) the sound poem 'Gadji beri bimba' from 1916, and (c) the video game Child of Light from 2014. These three cases differ considerably from one another in terms of period, expressional form, interpretation history, and classification as 'obviously' artistic and/or religious. Precisely because of these differences, it will be possible to illustrate the six perspectives on religious art I have described.

(1) The Isenheimer Altarpiece is, without a doubt, one of the most famous pieces of religious art in the Western world, and it has been discussed extensively by art critics and art scholars alike (Harrisville 2004; Hayum 1989; Mellinkoff 1988). The altarpiece is named after its original location, the church of St. Anthony's monastery in Isenheim, near Colmar (presently part of France), but it is currently situated in the Unterlinden Museum, also in Colmar. The altarpiece was sculpted by Nikolaus of Haguenau, and painted by Matthias Grünewald between 1512 and 1516, and it was made especially for the monastery of the Hospital Brothers at Colmar, who were famous for their care of plague sufferers and others afflicted by skin diseases. The image of Christ, central to the altarpiece, reflects this care, since the crucified is imagined as riddled with plague-like sores, thus indicating that God shares the afflictions of the sufferers (see also De Kesel's article later in this volume).

(2) 'Gadji beri bimba' is the German Dadaist Hugo Ball's (1886-1927) most famous 'sound poem', first performed during a soiree of the Cabaret Voltaire in Zürich in 1916. Ball and his fellow ('first-wave') Dadaists, like Marcel Janco (1895-1984), Tristan Tzara (1896-1963), and Richard Huelsenbeck (1892-1974), protested against the atrocities of the First World War by means of the deconstruction of conventional language itself (Bosman 2015, 2014). In this context, Ball created his Klanggedichte, a seemingly incoherent and random sequence of sounds, which nonetheless appeals to an a priori paradise-like (or 'Adamic') language in which the signifier and signified coincide (Kuenzli 1979).

The poem 'sounds' like this (as written by Ball himself), the first verse:

gadjama gramma berida bimbala glandri galassassa laulitalomini

gadji beri bin blassa glassala laula lonni cadorsu sassala bim

gadjama tuffm i zimballa binban gligla wowolimai ben beri ban

o katalominai rhinozerossola hopsamen laulitalomini hoooo

gadjama rhinozerossola hopsamen laulitalomini hoooo

gadjama rhinozerossola hopsamen

blulu tarullala blaulala loooo 
Ball, who later returned to the Roman Catholic Church of his youth, reinterpreted his sound performance in a passage in his diaries Flucht aus der Zeit ('Flight out of time') in overtly religious terminology (although we have to keep in mind that Ball severely edited his notes after his conversion, and the original is unfortunately beyond historical reconstruction):

Then I noticed that my voice had no choice but to take on the ancient cadence of priestly lamentation, that style of liturgical singing that wails in all the Catholic churches of East and West. (...) I began to chant my vowel sequences in a church style like a recitative. (...) For a moment it seemed as if there were a pale, bewildered face in my cubist mask, that half-frightened, half-curious face of a tenyear-old boy, trembling and hanging acidly on the priest's words in the requiems and high masses in his home parish. (...) I was carried down off the stage like a magical bishop (Elderfield 1996: 71).

In his diary, Ball connected the sound performance of the Cabaret Voltaire with the Latin-sung masses of the Roman Catholic liturgy, and imagines himself as its celebrating-cum-performing bishop (White 1998).

3. The video game Child of Light (Ubisoft 2014) - a single/two-player(s), two-dimensional, linearly told, single-ending role playing game with turnbased battle mechanics, set in a fantasy world-tells the story of Aurora, the young daughter of the Duke of Carniola, who dies on 'the Great Friday' 1895 from an unknown affliction. Aurora finds herself waking up in Lemuria, a mysterious underworld land, conquered and ruled by the dark queen Umbra. When Aurora sacrifices her own life to overcome Umbra's destructive magic, she is resurrected on Easter Sunday by her disappeared mother, the Queen of Light. After Umbra is defeated, she returns to Carniola, which she finds under threat from a great flood caused by a (historical) earthquake. She takes her people through a magic mirror to Lemuria, which is no longer a place of darkness and suffering, but of light, pleasure, and eternal life.

Child of Light tells multiple stories on different narratological levels (Bosman 2018). First of all, CoL is framed as a bedtime story, told by a now grown-up Aurora to her own daughter. Within that frame, the game also provides a more or less classical coming-of-age narrative in which Aurora develops from being a small, insecure girl into a confident and powerful queen. Furthermore, the game presents Aurora's adventures in terms of the prototypical hero descending into what the narratologist Joseph Campell (2008) has called 'the Belly of the Whale': the symbolic emptying of the hero's former identity by a seemingly unconquerable evil, which transforms him/her into a new character who is capable of saving the world. Finally, CoL also interprets Aurora's journey to the underworld in religious terminology, resembling that of the classical Christian-theological notion of the 
descensus Christi ad inferos, also known in English as the 'harrowing of hell' (Bosman 2018).

\section{Object: The Material-Religious Perspective}

The first perspective on religious art to be discussed here is the materialreligious one. Material-religious art is art that can directly and automatically be identified as religious in nature by at least a partially initiated viewer or listener. I use the terms (partially) initiated viewer/listener to mean that the observer of any given artistic object or performance is sufficiently culturally adapted to understand the basic religious and artistic concepts within a certain cultural atmosphere. The Matthäuspassion directly evokes religious imagery and vocabulary in our contexts, but is probably utterly unintelligible to people living in other parts of the world who have never been initiated into Christian mythology.

In the case of the material-religious perspective, the religious essence of the object is apparent, uncomplicatedly evoking associations with other explicitly religious objects, melodies or gestures. Those who wish to deny the religious identity of the object must carry the burden of proof, not vice versa. Let us see what happens if we look at our three case studies from this perspective: can the altarpiece, the poem, and the game be qualified as 'religious' (art)?

The Isenheimer Altarpiece easily qualifies as religious within this specific perspective. The images univocally reference figures and events from the Christian tradition, like the crucifixion and resurrection of Jesus Christ, the annunciation to the Virgin Mary, Saint John the Baptist, Saint Anthony the Great, Saint Sebastian, and so forth. Virtually every visitor of the Unterlinden Museum will immediately identify the Isenheimer Altar as a religious piece of art. Critics who wish to defend the opposite view-that the altarpiece does not qualify as a work of religious art-will have a rather difficult or even impossible task to perform.

It is exactly the opposite for Hugo Ball's sound poem. Not many-if any-of the audience members who watched the sound performance in 1916-it was performed in a pub in Zürich, not necessarily known for its classical or artistic identity-nor the majority of Ball scholars in later decades recognised and/or identified 'Gadji' as a religious piece of art. It was only towards the end of the $20^{\text {th }}$ century that scholars began to understand that the two constitutive elements of Ball's life-his earlier Dadaism and his later neo-Catholicism-had to be viewed together in order to understand the significance of one of Dada's legendary founders (Mann 1987, Wacker 1996, White 1998, Stock 2012, Braun and Teubner 2011, and Zehetner 2000). But it takes a lot of intellectual and scholarly effort to make the con- 
nection between 'Gadji' and Ball's religious biography, something which the average listener or reader cannot be expected to do.

The video game is somewhat of a mixed bag from this perspective. While the narrative of the game definitely refers to and makes extensive use of Christian imagery, notions and stories, it is not very likely that the average gamer would instantaneously recognise this as such. Much of the game's referential aesthetic-Aurora's incidental cross-form gesture, the use of stained glass with depictions of the moon, the sun and stars, earthquakes and floods and so forth-and its rhetoric-the use of Good Friday, Easter Sunday, resurrection, Aurora and so forth-are only recognisable to the trained eye and ear, especially since the religious content of the story of the game is only revealed slowly and subtly.

In short, from a material perspective, the Isenheimer Altar can be identified as religious art, while the poem and the game (the former more strongly so than the latter) cannot.

\section{Place: The Contextual-Religious Perspective}

The second perspective on religious art is the contextual-religious one. Contextual-religious art can be identified as such, again by the average culturally adapted viewer/listener, primarily-but not exclusively-by the location where the object or performance is situated, including its cultural context(s). Both the original and current context(s) of the artistic objects are significant. Works of art can be shown and/or performed in a rich variety of places and/or circumstances, and all of these influence its meaning and interpretation, including its religious connotations.

Mozart's Requiem can be-at least historically-heard as part of a regular funeral church service or in a classy concert hall. In addition to its obviously religious content, the context of the performance influences the religious interpretation of the performance: if performed during a church service, it is primarily a piece of religious liturgical music, while in a concert hall it will be presented, and probably perceived, as an artistic work of the highest quality.

The same applies to other artistic objects: it can be seen/heard in a museum, in the middle of a public square, in a private home, in an office, in a church, a cathedral or a chapel, hanging from the rear-view mirror of a car or lorry. The contextual-religious perspective focuses on the influence of the physical space where any given work of art exists upon its interpretation as religious.

If we look at our three case studies, it is clear that two out of three can be interpreted as 'religious' from their positioning in their physical and cultural context(s). The Isenheimer Altarpiece has both a historical and actual location which both contribute to its religious interpretation, although the 
former - the monastery of St. Anthony-invokes a stronger connection to the sacred than the latter-the Unterlinden Museum, but-as I have explained above-the ambience of a museum in the present day does not exclude religious or spiritual connotations and may even be thought of as producing those connotations, especially since the museum is partially situated in a deconsecrated church, which mergers the two contexts of church and museum even more.

Ball's sound poem 'Gadji', on the other hand, does not qualify as religious art from this perspective. On that faithful evening of 23 June 1916, when Ball premiered his sound poem, the Holländische Meierei café was filled with a very mixed audience, as was usually the case: experimental painters, war-weary fugitives, idealistic students, tough revolutionaries, some tourists, international scammers, prostitutes, and spies were the regulars of the Cabaret Voltaire, whose artistic content they can hardly have understood, let alone appreciated (Arp 1957:107, Janco 1957:29, Rubin 1969:63, Noguez 2015: 43).

The religious content of the performance and/or of the poem itself can only be found by observers who have the necessary knowledge of Dadaism in general and of Ball in particular, but this interpretation is not influenced by historical (1916) or later re-prints in literary or artistic magazines and performances of the poem by other artists and performers.

Nor can the third case study, Child of light, be interpreted as religious from the perspective of context. Games and gamers are usually not a 'space' where the religious realm is obviously present, although religious games, religion-in-game, and even gaming-as-religion are definitely a very interesting field of academic theological interpretation (Bosman 2019). But again, neither the classical arcade halls of the 1960s and 1970s, nor the PCs and consoles we have in our private homes have any direct connection with religion which might help to interpret a game as such.

\section{Direction: The Referential-Religious Perspective}

The third possible perspective through which an object or performance could be interpreted as religious is the referential-religious perspective. Referential-religious art relates to artistic objects or performances that refer to one or more elements from one or more religious and/or spiritual traditions. Recognising and interpreting art as religious in this way requires observers who are more than usually culturally adapted, but often it requires some need of expert knowledge and/or experience of the religious tradition(s) to which the work of art refers. The more implicit the reference is and/or the more culturally unknown the religious tradition to which the work refers is to the stereotypical observer, the greater the need for specific 
knowledge for the process of interpretation in general and for interpretation as a religious piece in particular.

This is most tangible when observing art from the distant past or-even more alienating-from a cultural Umwelt that is strange to us. Interpreting Chinese art is as difficult for us as interpreting the Matthäuspassion is to the average Chinese person, let alone if the Chinese art object in question itself refers to Taoism or Buddhism. The religious reference of the art in question can-of course-be subtle and implicit, or-on the contrary-very obvious and straightforward.

The Isenheimer Altarpiece uncomplicatedly refers to the Christian tradition, as an average West European observer will immediately see: all the scenes on all the panels of the altarpiece are depictions of Biblical stories and of later stories about Christian saints. The game Child of Light also refers to the Christian (and classical Hellenistic) tradition(s) - as far as theme, aesthetics, and rhetoric are concerned-but on a much more implicit level, specifically if we take into account that the game industry is not considered to be a place of religion per se.

To interpret CoL as a religious piece of art, the observer-or gamer-has to have some degree of Christian cultural education, something increasingly uncommon in our era of secularisation and religious de-verbalisation, the process of the collective and individual decrease in knowledge of and from Christian tradition, including the accompanying disappearance of religious, spiritual, and even existential vocalisations (Bosman 2019:29).

While an argument can be made that Ball's sound poem does refer to the Christian, or more precisely, to the Roman Catholic tradition, this requires a great deal of historical, literary and/or theological knowledge and expertise, and even then it is heavily dependent on Ball's own postconversion retrospective self-analysis, more specifically on his diary, as already quoted above. The Isenheimer Altarpiece, CoL, and 'Gadj' can be interpreted as religious from a referential-religious perspective, but such interpretations require a lot of expert knowledge.

\section{Contemplation: Reflexive-Religious Perspective}

The fourth perspective through which a work of art can be identified and/or interpreted as religious is the reflexive-religious one. Reflexivereligious art refers to artistic objects or performances that reflect, or to put it more precisely, stimulate the observer to reflect upon existential notions that are traditionally associated with the religious domain, like life/death, $\sin$ /forgiveness, suffering/salvation, and so forth.

Of course, this perspective is more subjective than the previous three, and it exists, to a greater degree than the latter, in the eye of the beholder. The object itself (material-religious), its place (contextual-religious), and the 
direction the art work points to (referential-religious) are more or less objective categories, at least for a culturally literate observer who has the necessary knowledge and expertise. The reflexive-religious perspective rests upon the observer's ability and willingness to be tempted by the object or performance to reflect upon existential notions.

Of course, cultural adaptivity and expertise do play a considerable role in this perspective, but the subjective element is more significant. In other words, the material, its place, and its references to the religious realm can assist the reflexive perspective, but they are neither a conditio sine qua non, nor a guarantee that the observer will be tempted to engage in existential reflection.

The Isenheimer Altarpiece is nevertheless easily identified as religious from a reflexive-religious perspective, on a subjective level, but without much effort also on a more intersubjective level. The culturally literate observer of the altarpiece will not be hard-pressed to at least imagine that this piece of art can stimulate people to reflect on existential notions. In addition to its general subject matter-a Christian-liturgical object-the specific characteristics of the altarpiece make such reflection almost obvious. As has been seen, the painter Matthias Grünewald chose to depict the crucified Christ riddled with skin sores in order to stimulate the religious identification between Christ and those who suffered from all kinds of skin diseases, for the treatment of which the monastery was famous. Also, the other saints-like Gregory the Great and Sebastian-are depicted in such a way that a connection between the saint and the sick observer could be easily made. As such, the Isenheimer Altarpiece stimulates the-at least historical-observer to contemplate his or her own life, the place of suffering within it, the struggle with the meaning (if any) of having to suffer disease, and the comfort that can be had from identification with the suffering Christ on the Altarpiece.

Ball's poem can also be interpreted as religious from this reflexive perspective, but-again - this requires a lot more work on the part of the observer. The Dadaistic project of the Cabaret Voltaire, of which Ball's sound poems are the most famous, but certainly not the only constituent, was aimed at causing shock and disassociation in its audiences, but was not infrequently met with incomprehension or even dismissal.

Nevertheless, observers who are sufficiently educated in the Dadaist project, its message of criticism of society, and in Ball's explicit idea of destroying conventional language by re-creating a kind of Adamic language, including his own-later-interpretation of his poems as reminiscences of Gregorian chant and Latin prayers, the actual modern audience of a sound poem performance could very well be stimulated to reflect upon its own notions of war and peace, of language both in its descriptive and performa- 
tive capacities, and of the frailness of humankind in the face of mass manipulation and extortion by the powerful.

Child of Light can also be interpreted as religious through a reflexivereligious lens, since it can be regarded as evoking reflexive behaviour in the gamers themselves, either because they are aware of its material, contextual and/or referential-religious potential, or because the game unconsciously and unreflexively evokes reflection, especially concerning the idea of the 'underworld' and the spiritual-emotional 'descent' into that metaphorical place. As Campbell has described, and as Christian mythology and theology aver in relation to Christ's descent into the underworld, the voyage of the archetypical hero-that is: each of us-also necessarily leads to an existential point of total psychological-emotional annihilation, from which the hero either returns stronger than ever before, or from which he never returns at all.

\section{Creator: Ritual-Religious Perspective}

The fifth perspective is the ritual-religious one, in which the religious interpretation of any given piece or art is rooted in the (perceived) intentions, (religious) virtues and/or biography of the creator of the object or performance. Connected to the Christian anthropological notion of humankind as created in God's image (Genesis 2), known as the imago Dei or theomorphism (Robinson 2016; Howell 2013; Middleton 2005), i. e. humankind as 'created co-creators' (Heffner 1993, 1989, 1996), this perspective focuses on the idea that the artist is engaged in a sacred act of imitation, mirroring in his or her own creative act the creative act of the Creator (Bosman 2019: 65-66). The process of creating art-or indeed creating anything-can be described in terms of ritual, an expression of the perceived relationship between the immanent and the transcendent, which simultaneously testifies to and evokes the divine (Conforti 1997: 54; Bohlman and Engelhardt 2016).

The difficulty of this perspective-or rather the challenge it poses-lies in the epistemological impossibility of obtaining insight into the creator's thoughts, intentions, and reflections, even when the artist has chosen to name or describe his artwork, or is actively engaged in dialogue with colleagues, fans, critics, and scholars. The ritual-religious perspective is vulnerable to the danger that no creator can be perfectly aware of his or her own thought processes, inspirational sources, and existential questions, which could lead to a kind of criticism that thinks that 'the reader knows better than the author'. This criticism is not always valid, I would argue, but the ritual-religious perspective is still susceptible to it.

When the Isenheimer Altarpiece is discussed from this perspective, another problem of the ritual-religious perspective becomes clear: the absence of any direct evidence or even the inaccessibility of this kind of material is 
almost insurmountable when the creator's work lies further in the past. It is not unlikely that Grünewald, who was raised in, worked in the context of, and produced work for a mono-religious society as Europe was at the time, did indeed conceive of his artistic labour as a religious act, a ritual, in itself. Unfortunately, this is only speculation.

It is easier to gain access to the ideas of Ball and the creators of Child of Light, since both date from much more recent times: 1916 and 2014. And as we have seen earlier in this article, Ball devoted many words to the interpretation of his own work in general, and to his sound poems in particular. Especially in his enigmatic essay Byzantinisches Christentum (1923), Ball seems to have created a new transcendent interpretation of himself and his former Dada project in the form of a 'sound theology', in which Gottes Ursprach ('God's primordial voice/language') is connected to the lives of early Christian saints like John Climacus, Dionysius the Areopagite, and Simon Stylitus, but also, though more implicitly, to his own sound poems from the Cabaret Voltaire (Bosman 2014). Although it remains implicit, it is easier to identify 'Gadj' as religious in a ritual perspective, because of Ball's own words.

The game Child of Light is the most recent of our case studies, so finding information about the creators and their (religious) inspiration or ritual identification should be an easy task. Unfortunately, as is the case with many creators of video games, finding evidence of religious inspiration is extremely difficult, for reasons that we can only speculate on. Maybe there is a commercial rationale: identifying religious inspiration could harm the economic success of the game. Director Jeffrey Yohalem is on record discussing the poetic structure of the game story (Steinman 2015), its anchoring in historical events (Lewis 2015), the use and significance of fairy tales (Harman 2015), and so forth, but nothing is to be found about the game's obvious Christian references and-possibly-meaning. The identification as religious from a ritual perspective is, therefore, unsure and speculative.

\section{Impact: Existential-Religious Perspective}

The final perspective on religious art is the existential-religious one, and it is easily the most subjective of the six. From an existential-religious perspective, art is religious when the observer has the experience that the divine is evoked through the interaction between him- or herself and the artistic object. The object itself has become divine and the source of and catalyst for spiritual, mystical, and/or existential experience. As has been said, this perspective is highly individual and subjective, since one and the same artistic object will evoke mystical rapture in one observer, but leave someone else completely unimpressed. 
This quality is attributed to icons, especially in the Orthodox tradition. As John Chryssavgis (2012:83) summarises:

The vision and the veneration of an icon become an immediate and intimate encounter between the believer and the depiction, reflected in the mysticism of the solitary burning of a candle and the movement of the dense could of incense that fill every Orthodox church.

The art may contain, evoke, symbolise, whisper, tell, associate, or whatever word one would like to use, the divine, but only in as much as the observer is willing to understand this as such, or to put it more precisely, in as much as the observer experiences the religious evocations of the object within him- or herself.

All three case studies could be regarded as religious from the existential perspective, as long as the Isenheimer Altarpiece, the sound poem, and/or the video game evoke the experience of the divine in the observer, be it a visitor to the Unterlinden Museum, a reader of Ball's Flucht aus der Zeit, in which the poem is quoted by Ball himself, or a gamer involved in Ubisoft's latest release.

\section{Final remarks}

Art and religion are two concepts that are instantly understandable for people, but are at the same time notoriously difficult to define. In both past and present, the two realms of art and religion have been intertwined, sometimes to their mutual benefit, sometimes in conflict and denial. Nevertheless the question as to how religion-be it institutionalised or eclectic and personal-and art are related to one another remains relevant.

In this paper I have given six, non-mutually exclusive possible perspectives on that relationship: (1) the material-religious perspective focusing on the material object itself; (2) the contextual-religious perspective focusing on the location of the object; (3) the referential-religious perspective focusing on the cognitive 'direction' of the artistic object, that is, to what religious notions, phrases, and so forth the object refers; (4) the reflexive-religious perspective focusing on the perceived ability of the object to evoke existential reflection within the observer; (5) the ritual-religious perspective focusing on the religious 'character' of the creator and his or her experience of the process of creating qualified as religious in itself; and (6) the existentialreligious perspective focusing on the perceived ability of the object to evoke an experience of the divine within the observer.

What is-and what is not-religious art depends strongly, if not exclusively, on the preposition and interpretation of the viewer/listener, although the material depiction of the object, the artist's explanation, and the context in which the art is displayed, can suggest a preliminary positive identifica- 
tion as such. This matrix of possibly intertwined perspectives on the relationship between art and religion can enhance our collective grasp of already existing reflections on this relationship, and/or those that are still to be written.

\section{Bibliography}

Adams D and Apostolos-Cappadona D (1987) Art as religious studies. Insights in the Judeo-Christian traditions. In idem (eds) Art as religious studies. Eugene: Wipf and Stock Publishers, pp. 3-11.

Alexander E and Alexander M (2008) Museum in motion. An introduction to the history and functions of museum. Second edition. Lanham: Rowman \& Littlefield.

Arp H (1957) Dadaland. In Arp H, Huelsenbeck R, and Tzara T (eds) Die Geschichte des Dadaismus. Dichtung und Chronik der Gründer, Zürich: Die Arche.

Bennett R, Kerrigan F, and O'Reilly D (2012) Introduction. In idem (eds) New horizons in art, heritage, nonprofit and social marketing. London: Routledge.

Ball H (1996) Flight out of time, edited by Elderfield J. London: University of California Press.

Bohlman Ph and Engelhardt J (2016) Resounding transcendence. An introduction. In idem (eds), Resounding transcendence. Transitions in music, religion, and ritual. New York: Oxford University Press.

Bosman F (2019) Gaming and the divine. A new systematic theology of video games. London: Routledge.

Bosman F (2018) The bell tolled six on Easter Sunday. The motif of the harrowing of hell in the video game Child of Light. In Sarot M and Wieringen A van (eds) The Apostles' Creed. 'He Descended into hell'. Leiden: Brill, pp. 160-184.

Bosman F (2015) Die Laute von Byzanz. Byzantinisches Christentum: zur fehlenden Verbindung zwischen Dada und Catholica im Leben Balls. Hugo Ball Almanach 6: 71-91.

Bosman F (2014) 'Gottes Ursprache'. Hugo Ball's Theology of Sound. In Lintner M (ed) God in Question. Religious language and secular languages, Brixen: A. Weger, pp. 397-412.

Braun M and Teubner T, eds (2011) Hugo Ball. Der magische Bischof der Avantgarde. Heidelberg: Das Wunderhorn.

Brown F (2014) Introduction. Mapping the terrain of religion and the arts. In idem (ed) Religion and the arts. Oxford: Oxford University press, pp. 1-24. 
Brown F (2000) Good taste, bad taste, E Christian taste. Aesthetics in religious life. New York: Oxford University Press.

Buggeln G (2015) Museum space and the experience of the sacred. The journal of objects, art and belief 8(1): 30-50.

Campbell J (2008) The Hero with the Thousand Faces, Novato: New World Library.

Casanova J (2009) The religious situation in Europa. In Wiegandt K and Joas $\mathrm{H}$ (eds) Secularization and the world religions. Liverpool: Liverpool University Press.

Chyssavgis J (2012) Orthodox spirituality. In Tyler P and Woods R (eds.), The Bloombury Guide to Christian spirituality. London: Bloomsbury, pp. 8293.

Cobb K (2005) The Blackwell guide to theology and popular culture. Oxford: Blackwell publishing.

Conforti P (1997) Spirituality. In Winiarski M (ed.), HIV Mental health for the 21st Century. London: New York University Press.

Dalgleish G (2000) Myths and realities of Jacobite relics. In Fladmark J (ed) Heritage and museums. Shaping national identity. London: Routledge, pp. 91-102.

Davies S (1991) Definitions of art. London: Cornell University Press.

Dillenberger J (1998) The religious art of Andy Warhol. New York: Continuum.

Duncan C (1994) Art museums and the ritual of citizenship. In Pearce S (ed) Interpreting objects and collections. London: Routledge, pp. 279-186.

Flanagan K (2001) Religion and modern personal identity. In Harskamp A van and Musschenga A (eds) The many faces of individualism. Leuven: Peeters.

Frayling C (2011) On craftmanship. Towards a new Bauhaus. London: Oberon Books.

Groot K de (2018) The liquidation of the church. London: Routledge.

Harman S (2015) Child of Light is a dark fairy tale RPG brimming with potential. VG247.com, www.vg247.com/2014/04/03/child-of-light-is-a-darkfairy-tale-rpg-brimming-with-potential [accessed 11-05-19].

Harrisville R (2004) Encounter with Grunewald. Currents in theology and mission 31(1): 5-14.

Hauser A (1965) Mannerism. The crisis of the renaissance and the origin of modern art. Cambridge: Belknap Press.

Hayum A (1989) The Isenheim alterpiece. God's medicine and the painter's vision. New York: Princeton University Press.

Hefner P (1989) The evolution of the created co-creator. In Peters T (ed) Cosmos as creation. Science and theology in consonance. Nashville: Abingdon.

Hefner P (1993) The human factor. Evolution, culture, and religion. Minneapolis: Fortress Press. 
Hefner P (1996) Theological perspectives on morality and human evolution. In Richardson W and Wildman W (eds) An evolving dialogue. Theological and scientific perspectives on evolution. Harrisburg: Trinity Press International.

Howell B (2013) In the eyes of God. A metaphorical approach to biblical anthropomorphic language. Cambridge: Pickwick Publications.

Howes G (2007) The art of the sacred. An introduction to the aesthetics of art and belief. London: I.B. Tauris.

Janco M (1969) Dada créateur. In Verkauf W (ed) Dada, monographie d'un mouvement, Teufen: A. Niggli.

Joas H (2009) The religious situation in the USA. In Wiegandt K and Joas $\mathrm{H}$ (eds) Secularization and the world religions. Liverpool: Liverpool University Press.

Koestlé-Cate J (2016) Art and the church. A fractious embrace. Ecclesiastical encounters with contemporary art. London: Routledge.

Korte A-M (2014) Blasphemous feminist art. Incarnate politics of identity in postsecular perspective. In Braidotti R, Blaagaard B, Graauw T, Midden $\mathrm{E}$, and Graauw $\mathrm{T}$ de (eds) Transformations of religion in the public sphere. New York: Palgrave/MacMillen, pp. 228-248.

Kuspit D (2005) The end of art. New York: Cambridge University Press.

Kuenzli R (1979) The Semiotics of Dada Poetry. In Foster S and Kuenzli R (eds) Dada Spectrum: The Dialectics of Revolt, Iowa City: The University of Iowa, pp. 52-70.

Lewis A (2015) Child of Light. Stories Behind the Stories. Ubi.com, http://blog.ubi.com/child-light-stories-behind-stories [accessed 11-05-19].

Mann Ph (1987) Hugo Ball. An Intellectual Biography. London: Institute of Germanic Studies.

Martland T (1981) Religion as art. An interpretation. Albany: State University of New York Press.

Mellinkoff R (1988) The devil at Isenheim. Reflections of popular belief in Grünewald's alterpiece. Berkeley: University of California Press.

Middleton J (2005) The liberating image. The Imago Dei in Genesis 1. Grand Rapids: Brazos Press.

Molendijk A (1999) In defence of pragmatism. In Platvoet J and Molendijk A (eds) The pragmatics of defining religion. Contexts, concepts, and contests. Leiden: Brill, pp. 3-22.

Morris P (2014) The end of multiculturalism? Religion, sovereignty and the nation state. In Mansouri F and B'béri B de (eds) Global perspectives on the politics of multiculturalism in the 21st century. London: Routledge.

Nicholis B (1979) Contextualization a theology of gospel and culture. Vancouver: Regent College Publishing. 
Noguez D (2015) Lenin dada. Essay, translated and edited by Straumann P and Morgenthaler J. Zürich: Limmat Verlag.

Otto R (1917) Das Heilige. München: C. H. Beck.

Paine C (2013) Religious objects in museums. Private lives and public duties. London: Bloomsbury.

Prodan S (2014) Michelangelo's Christian mysticism. Spirituality, poetry, and art in 16th century Italy. New York: Cambridge University Press.

Robinson D (2016) Understanding the 'Imago Dei'. The thought of Barth, von Balthasar and Moltmann. London: Routledge.

Rubin W (1969) Dada and surrealist art, London: Abrams.

Sassower R and Cicotello L (2000) The golden Avant-garde. Idolatry, commercialism, and art. London: University Press of Virginia.

Sauerländer W (2011) Der Katholische Rubens. Heilige und Märtyrer. Münich: C.H. Beck.

Sedlmayr H (2017) Art in crisis. The lost center. Milton: Taylor and Francis.

Siedell D (2015) Who's afraid of modern art? Essays on modern art and theology in conversation. Eugene: Cascade Books, pp. 44-65.

Simmons J (2016) Museums. A history. Lanham: Rownman \& Littlefield.

Stakemeier K and Vishmidt M (2016) Reproducing autonomy. Work, money, crisis, and contemporary art. Berlin: Mute Books.

Steinman G (2015) Child of Light. Poetry in Motion. Ubi.com, http://blog.ubi.com/child-light-poetry-motion [accessed 11-05-19].

Stock W-M (2012) Denkumsturz. Hugo Ball. Eine intellektuelle Biographie, Göttingen: Wallstein Verlag.

Streib H (2007) Religious Praxis-de-institutionalized. Theoretical and empirical considerations. In idem (ed) Religion inside and outside traditional institutions. Leiden: Brill.

Usselmann N (2018) A sacred look. Becoming cultural mystics. Theology of popular culture. Eugene: Wipf and Stock Publishers.

Wacker B, ed (1996) Dionysius DADA Areopagita. Hugo Ball und die Kritik der Moderne. Paderborn: Schöningh.

White E (1998) The Magic Bishop. Hugo Ball, Dada Poet. Columbia: Camden House.

Zehetner C (2000) Hugo Ball. Portrait einer Philosophie. Vienna: Turia und Kant (2000). 